\title{
КОНЦЕПЦИЯ РАЗВИТИЯ ОХОТНИЧЬЕГО ХОЗЯЙСТВА НА ТЕРРИТОРИИ ЛЕНИНГРАДСКОЙ ОБЛАСТИ В.М. Тарбаева ${ }^{1}$, А.А. Кожаев ${ }^{2 *}$, М.В. Шахин ${ }^{2 *}$ \\ ${ }^{1}$ Санкт-Петербургское региональное отделение Российской экологической академии \\ и 2 Западный филиал ГНУ Всероссийский научно-исследовательский институт охотничьего хозяйства и звероводства им. проф. Б.М. Житкова (Санкт-Петербург, Россия) \\ Эл.noчma:tarbaeva@yandex.ru; *west_vniioz@mail.ru \\ Статья поступила в редакцию13.01.2015; принята к печати 28.02.2015
}

Разработка концепции развития охотничьего хозяйства на территории Ленинградской области на десятилетний период невозможна без учета исторического опыта и результатов громадного социально-экономического эксперимента, поставленного самой историей нашей страны. Экономические потрясения, различные социальные проявления, политические приоритеты, законодательная нестабильность определяли состояние охотничьего хозяйства России в последние 20 лет. Поэтому в настоящий период важно дать объективную оценку состояния в этой сфере природопользования, показать необхдимость принимать за основу биологические принципы при определении приоритетов и основных направлений государственной политики во всех сферах деятельности, а также учитывать их при долгосрочном социально-экономическом планировании развития как субъектов Российской Федерации, так и страны в целом. В этой работе предпринята попытка осветить вопросы общей теории охоты, виды и методы практической деятельности, дать исторический обзор охотничьего хозяйства Ленинградской области за последние 30 лет и выработать рекомендации по улучшению состояния в этой сфере в Ленинградской области на десятилетнюю перспективу.

Ключевые слова: охотничье хозяйство, охота, концеепция, природопользование.

\section{A CONCEPT OF THE DEVELOPMENT OF HUNTING RESOURCES IN LENINGRAD OBLAST}

\author{
V.M. Tarbayeva ${ }^{1}$, A.A. Kozhaev ${ }^{2}$, M.V. Shakhin ${ }^{2}$
}

${ }^{1}$ Saint-Petersburg Regional Branch of the Russian Ecological Academy and ${ }^{2}$ Western Branch of B.M. Zhitkov All-Russian Research Institute of Hunting Resources and Fur Breeding (Saint Petersburg, Russia) E-mail: tarbaeva@yandex.ru; *west_vniioz@mail.ru

Working out of a concept of the development of hunting resources in Leningrad Oblast projected to decades ahead is impossible without considering the course and results of the tremendous socioeconomic experiment undergone by this country in its recent history. Economical perturbations, social turmoils, political priorities, and legal uncertainty were the factors that determined the state of hunting resources in Russia over the past two decades. Therefore, it is expedient now to assess in an objective way the current state of affairs in this field of nature management, to consider biological principles while defining priorities and main directions of state policy in this and all related fields, and to account of all that in long-term socioeconomic planning for every subject of the Russian Federation and for the whole nation. The present publication is an attempt to shed light on the basics of the general theory of hunting and on specific modes and methods of hunting practice, to provide a retrospective review of hunting resources in Leningrad Oblast over the last 30 years, and to work out recommendations for improving this sphere of human enterprise in Leningrad Oblast for a decade ahead.

Keywords: hunting resources, hunting practice, concept, nature management.

\section{Теоретические основания разработки концепции развития охотнИчьИх хозяйств}

В отечественном законодательстве укоренилось понятие концепции как совокупности (системы) представлений о стратегических целях и приоритетах политики государства в той или иной сфере, важнейших направлениях и средствах реализации этих целей (Постановление Правительства РФ от 2 августа 2001 г. № 576 «Об утверждении Основных требований к концепции и разработке проектов федеральных законов»). В научной трактовке концепция - определенный способ понимания явлений, представление о конструктивном принципе какойлибо деятельности. Так или иначе, по отношению к самой деятельности концепция служит алгоритмом перевода теоретических воззрений в практические стратегии, своеобразным посредником между ними.
Вытекающие из конкурирующих теорий множественные концепции обусловливают часто противоположные оценки прошлого, текущего и желательного состояния рассматриваемых явлений и, соответственно, различные программы практических действий. В связи с этим в Концепцию включено изложение теоретических воззрений, на которые она опирается и которые, посредством Концепции, будут воплощены в планах и действиях по их реализации.

В охотоведении отсутствуют оформленные, консолидированные теории охоты и охотничьего хозяйства. Ниже представлено краткое обобщение теоретических представлений о содержании, противоречиях и тенденциях развития охоты и охотничьего хозяйства. При этом в данное рассмотрение включается, в отличие от известных разработок:

- гораздо более широкий, как географически, так и хронологически, опыт охотпользования; 
- альтернативные (теоретически равноценные и практически равновозможные) варианты развития отраслевых процессов;

- гуманитарные аспекты охотпользования и, в связи с этим, аксиологические (ценностные) подходы к выбору предлагаемых вариантов.

Большинство антропологов исходит из того, что склонность человека к охоте имеет генетическую обусловленность. Вместе с тем, известны авторитетные утверждения, согласно которым гоминиды стали охотиться лишь через полтора миллиона лет после своего появления. Различие между генетической и адаптивной концепциями охоты имеет практическое значение, поскольку адаптации заведомо преходящи, а генетически обусловленные потребности рассматриваются как «натуральные», «природные», витальные, восходящие в понятие «человеческого естества» и потому не поддающиеся (и не подлежащие) внешнему, в том числе властному, регулированию [7].

В теории права, например, в этом аспекте противостоят, с одной стороны, естественно-правовое учение, согласно которому «естественные», «первоначальные» права человека неотъемлемы и не подлежат произвольному умалению кем бы то ни было, в том числе государством, и, с другой, различные течения, утверждающие всесилие закона, руководствующегося соображениями текущей целесообразности [7].

В социологии и политологии на разных полюсах находятся элитаристы, утверждающие неизбежность формирования устойчивых элит, обладающих привилегиями, в том числе охотничьими, и эгалитаристы, настаивающие на необходимости обеспечения равенства доступа ко всему, что рассматривается людьми как благо [7].

Футурологи, склонные описывать человеческую историю в категориях прогресса, характеризуют охоту как отмирающий пережиток. К ним примыкают (макро)экономисты, отмечающие приближение к нулю материального значения охоты в индустриальных и постиндустриальных цивилизациях. Культурологи и историки, фиксируя неизменную устойчивость охотничьей активности, относятся к охоте как к важному элементу наследия, заслуживающему уважения и охраны; при этом и они могут смотреть на будущее охоты с финалистических позиций, предвидя ее исчезновение. Традиционалистами, как правило, являются и этнологи (в частности, североведы), для которых несомненна включенность охоты в образ жизни, ментальность этносов, являющихся преимущественными объектами их исследования, они продолжают будущее охоты в бесконечность [11].

Часть психологов, соглашаясь с наследственным (генетическим или социальным) статусом охоты, считают ее, однако, наследием деструктивным, разрушительным, не вписывающимся в картину современного мира, движущегося к терпимости, всеобщему согласию и тому подобному. Другие утверждают, что именно первобытные охотничьи общества были самыми мирными человеческими сообществами из всех известных, и (или) полагают, что доброкачественная, в том числе, охотничья, агрессивность важный приспособительный инструмент, не утрачивающий своей ценности в спектре человеческих возможностей [7].

В данном контексте следует упомянуть две важнейшие концепции.
Одна из них - экологическая - в своей естественнонаучной части не имеет сильной оппозиции в научной сфере в силу доказательности своих ценотических построений и эффективности практических приложений (например, управления популяциями животных). Экологисты-пропагандисты, провозвестники экологической катастрофы, утрачивают научные позиции в связи с опровержением их прогнозов [6].

Вторая - эколого-этическая, настаивающая на переходе от антропоцентризма к био(зоо, эко)центризму, в строго философских вариантах лежит, как и вся философия, вне сферы науки и противостоит традиционному философскому гуманизму, полагающему именно человека «мерой всех вещей». Вне науки - и многочисленные религиозно-этические версии экологических течений $[4,6]$.

В различных вариантах и комбинациях все эти представления отражаются в частнонаучных исследованиях, интерпретируются в популярной литературе, присутствуют в обыденном сознании и, в конечном счете, влияют на принятие управленческих решений в охотхозяйственной сфере.

Приведенные выше положения частных наук могут быть сгруппированы в две основные теории охоты.

Одна - финалистическая - исходит из того, что охота - наследие древности (воспринимаемой как дикость), первобытный инстинкт или обычай, воспроизводящий агрессивные стереотипы, теряющий экономическое значение и угрожающий устойчивости окружающей среды. В современном мире растущих экономик и возвышающих этик охота - вредный и опасный атавизм (архаизм), естественное отмирание которого можно и нужно ускорять влиянием общественного мнения и силой государственной власти [9].

Вторая - открытая, или органическая, - опираясь на непрерывность феномена охоты, полагает ее сущностным, неустранимым компонентом человеческой природы, проявления которого нейтральны или положительны с точек зрения этики и экологии. Падение экономического значения охоты не умаляет, а делает еще более наглядной ее непреходящую социокультурную значимость. Охотничья активность внутренне присуща (имманентна) человечеству, и охотники, независимо от их численности, не подлежат общественному суду большинства и дискриминации со стороны государства, что не исключает установления экологических и технических ограничений [7].

Обе вышеописанные теории охоты допускают существование двух противоположных концепций организации охоты - элитарной (корпоративной) и эгалитарной (основанной на всеобщности).

Элитарная концепция характерна (в западном мире) для Европы и основывается на признании правомерности персонифицированного ограничения доступа граждан к охоте со стороны других граждан. В русле модернизированной монархической традиции дарования (октроирования) избранным лицам охотничьих прав современное право доступа к охоте определяется принадлежностью гражданина к какой-либо корпорации (землевладельцев, членской организации и прочих). Государство может учреждать такие корпорации, активно регулировать их деятельность или, напротив, придавать им статус самоуправляемых. Во всех случаях неизбежным результатом является фак- 
тическое установление имущественных или статусных охотничьих цензов $[12,17]$.

Эгалитарная концепция, общепринятая в США и Канаде, признает регулирование доступа к охоте прерогативой государства; при этом функция последнего - обеспечение максимально свободного и равного доступа к охоте претендентов. Право охоты не зависит от принадлежности к корпорациям, равенство доступа обеспечивается использованием механизмов случайного выбора претендентов [13].

Обе эти концепции и соответствующие им практические стратегии преодолевают дисбаланс между спросом на охоту и ее (недостаточным) предложением, однако делают это различными способами. Европейская схема обеспечивает ограничение числа охотников вообще, и из них - реально охотящихся и, далее - занимающихся наиболее популярными видами охот. Североамериканская схема стимулирует рост числа охотников, ограничивая их охотничью активность с соблюдением принципов равенства, дополняемых соображениями справедливости. Первая из них устойчиво предоставляет лучшие охотничьи возможности социально успешным, вторая - равные возможности каждому $[12,13]$.

\section{Концепции организации охотничьего хозяйства}

С вышеописанными концепциями организации охоты тесно связаны концепции организации охотничьего хозяйства и само понимание хозяйствования.

Элитарная концепция предполагает существование локальных охотхозяйств, принадлежащих правительственным, квазиправительственным или неправительственным корпорациям и частным лицам, которые вправе устанавливать и (или) реализовывать ограничительные стратегии доступа к охоте. Применяются финансовые, территориальные, регальные, поземельно-имущественные и иные механизмы, способные обеспечить подавление роста общей численности охотников и охотничьей активности наименее состоятельной (в различных социальных отношениях) части охотников.

Эгалитарная концепция, основанная на принципах всеобщности, равенства и справедливости, отрицает допустимость введения ограничений, пресекающих охотничью активность отдельных граждан или их групп (слоев). Недопустима, следовательно, и широкая организация корпоративно управляемых охотхозяйств, имеющих возможность легально отказывать гражданам в охоте по индивидуальным или групповым критериям, устанавливаемым корпорациями. В рамках этой концепции государство управляет охотничьими ресурсами и регулирует доступ к ним; корпорации допускаются лишь к организации доступа граждан к охоте на определяемых государственными органами социально приемлемых условиях [8].

\section{Выбор концепции организации отрасли}

\section{в Ленинградской области}

И североамериканская, и европейская модели охотничьего хозяйства могут рассматриваться как эффективные. Выбор стратегии носит политический характер. Необходимой предпосылкой такого выбора является оценка соответствия национальным социально-природным реалиям и региональным особенностям $[1,8]$.
Выбор концепции конструктивного принципа организации охотничьего хозяйства Ленинградской области должен учитывать следующие обстоятельства. И элитарная, и эгалитарная концепции обеспечивают соответствие охотпользования современным экологическим требованиям. Вместе с тем, элитарная концепция апробирована только в густонаселенных районах, а эгалитарная продемонстрировала свою успешность независимо от людности территории.

История России, ее экономико-географические, демографические и иные характеристики обусловили незначительность влияния современных религиозно-этических движений. Охота не рассматривается как сомнительная с моральной точки зрения деятельность, ее будущее не ставится под сомнение. Бытующие в обществе представления в целом соответствуют органической теории охоты.

В Российской Федерации фактически отсутствует как частная собственность на землю вне поселений, так и прямая связь землевладения с охотпользованием. По этим параметрам, имеющим важнейшее значение для организационного устройства охотничьего хозяйства, Россия кардинально отличается от Европы и сближается с Северной Америкой, где сохраняются обширные массивы публичных земель (земель Короны), а за землевладельцами закрепляются лишь некоторые охотничьи привилегии (обусловленные защитой сельскохозяйственного производства) [10].

Конституция Российской Федерации провозгласила ее «социальным государством, политика которого направлена на создание условий, обеспечивающих достойную жизнь и свободное развитие человека». Это положение трактуется доктриной как приоритетность социальных интересов над прочими, например, финансовыми или идеологическими.

К настоящему времени российское государство полностью утратило непосредственный интерес к продукции охоты, ранее жестко включенной в налогово-бюджетные механизмы. В случаях, когда охота жизненно важна для отдельных групп населения, эта потребность имеет ярко выраженное социальное, но не экономическое значение (охота как отрасль действительно «народного хозяйства», в досоветском значении термина).

Реализация элитарных конструкций действующего фаунистического законодательства приводит ко все большему расширению практики организаций в лучших охотничьих угодьях охотхозяйств жестко ограниченного доступа, принадлежащих, явно или неявно, верхушке центральных и местных элит. Очевидность имущественно-должностного основания охотничьих привилегий приводит к обострению социальной напряженности, внешняя легитимность дискриминации рядовых охотников обусловливает проявление недовольства деструктивными методами.

Важными представляются также следующие обстоятельства:

- за последние десятилетия в России не сформирована единая централизованная государственная служба управления охотничьим хозяйством, действующая по единым принципам;

- невысокий уровень доходов подавляющей части граждан России позволит обеспечить необходимые объем и степень самофинансирования управленческого сектора отрасли только путем увеличения числа охотников и повышения их охотничьей активности; 
- практика европейских государств и меж(над)государственных структур дает основания полагать, что процесс элитаризации охоты, будучи связанным с отрицанием естественных оснований охотничьей активности, с неизбежностью приводит к сужению социальной базы охоты, падению ее общественного престижа и, в конечном счете, затуханию охотничьей активности.

В Ленинградской области надо учитывать следующие факторы:

- в связи с близостью мегаполиса, преобладанием городского населения и обезлюдением сельских населенных пунктов сохранились обширные малонаселенные территории;

- охотничьи ценности и традиции не подвергаются сомнению в общественном мнении и пользуются поддержкой органов власти;

- сложилось отношение к традиционному природопользованию как социально значимому сектору экономики;

- доля земель, находящихся в частной собственности, крайне незначительна;

- отлажены механизмы взаимодействия органов государственной власти с представителями крупного бизнеса;

- имеются ресурсы для формирования собственной службы управления охотничьим хозяйством с районным звеном.

Российская конституция гарантирует право на равный доступ к природным ресурсам, а также право на труд, право на отдых и другие права, совокупность которых применительно к охоте соответствует эгалитарной концепции. Вместе с тем, российское законодательство не определяет статус охоты, природу охотничьих прав (косвенно считая их предоставляемыми, а не «естественными») и не устанавливает необходимость их государственной защиты. Оно предусматривает альтернативный, государственнокорпоративный порядок предоставления права на охоту и допускает массовое создание частных охотничьих хозяйств ограниченного доступа.

Отечественное законодательство, предусматривая на уровне обычных законов и подзаконных нормативных правовых актов элементы элитарных конструкций, на более высоком уровне, в том числе в форме конституционных положений, содержит предпосылки (и обязательства) реализации эгалитарной модели организации охоты.

Важно подчеркнуть, что в чистом виде ни элитарная, ни эгалитарная концепции организации охотничьего хозяйства в крупных странах не реализуются. Речь идет именно о концептуальном выборе: или охотничье хозяйство организуется для элиты с некоторыми демократическими допущениями, либо оно организуется, исходя из принципов равенства доступа к охоте, но с некоторыми, территориально ограниченными, возможностями исключительного доступа.

\section{Исторический обзор развития охотничьего} хозяйства в Ленинградской области за период с 1980-х г2. по настоящее время

Данный обзор необходимо учесть при создании Концепции в связи с тем, что охотничье хозяйство Ленинградской области за последние 35 лет разви- валось по различным моделям: и элитарной, и эгалитарной, и по смешанной теории охоты. Другими словами, на территории Ленинградской области за эти годы был поставлен эксперимент как для целого субъекта Российской Федерации, площадью 7,5 млн га. Изучение и анализ его результатов дает ответы на вопросы целесообразности выбора той или иной модели Концепции.

Последние годы существования СССР до 1991 г. сферу охотничьего хозяйства Ленинградской области можно охарактеризовать как достаточно стабильную отрасль экономики. В этот период около 85\% охотничьих угодий были закреплены за охотпользователями: общественными организациями охотников, отдельными промышленными предприятиями и научными организациями. Оставшиеся 15\% составляли заказники и угодья общего пользования под непосредственным контролем Леноблохотуправления [5].

В этот период охотпользователи-общественные организации существовали на принципах самоокупаемости, получая средства от членских взносов, охотхозяйственной деятельности и от оказания различного рода услуг населению.

Численность основных видов охотничьих животных поддерживалась на высоком уровне при достаточно интенсивной эксплуатации их поголовья. Так, численность лося составляла 22,0-24,0 тыс. особей, и ежегодно добывалось до 3,0 тыс. особей; численность кабана составляла 5,0-7,0 тыс. особей при ежегодной добыче около 1,5 тыс. особей. Ежегодно добывалось около 100 особей медведей при численности около 1,5 тыс. особей. Запасы пушных зверей: бобров, куниц, норок, лисиц, енотовидных собак - интенсивно опромышлялись, хотя в заготовительные организации поступал не весь объем пушно-мехового сырья. Между охотниками, добывающими пушных зверей, была большая конкуренция.

Охотники самостоятельно проводили учеты численности пушных зверей на всей территории Ленинградской области. Регулирование численности волков всячески стимулировалось и поощрялось, в результате чего ежегодная добыча составляла до 400 особей. Биотехнические мероприятия проводились практически на всей территории Ленинградской области, но, кроме того, сельхозпроизводители оставляли до 50\% урожая зерновых и картофеля, который уходил под снег и использовался дикими животными. Учеты численности охотничьих животных регулярно проводились на всей территории Ленинградской области, и действовал принцип: нет учетанет охоты. Общественные организации охотников, кроме охотхозяйственной деятельности и оказания услуг, проводили работу по подготовке кандидатов в члены обществ, имели секции юных охотников, поощряли общественную активность в целях ведения охотничьего хозяйства, вели воспитательную работу посредством дисциплинарно-товарищеских комиссий. Система охотнадзора действовала достаточно эффективно благодаря тому, что имелся штат государственных охотинспекторов, штат егерей и охотоведов охотпользователей, а также общественных охотинспекторов, общая численность которых доходила до 1000 человек. Кроме непосредственного надзора в охотничьих угодьях существовали методы прикрепленного надзора, когда при обнаружении 
шкуры лося или кабана в охотничьих угодьях можно было констатировать факт незаконной охоты, и это было основанием для возбуждения уголовного дела правоохранительными органами. Практически все виды охот проводились под контролем либо государственных инспекторов, либо штатных работников охотпользователей [5].

Таким образом, уже в 1980-х гг. была практически решена большая часть положений современной «Стратегии развития охотничьего хозяйства Российской Федерации на период до 2030 года», утвержденной распоряжением Правительства РФ от 03.07.2014 г. № 1216-p.

В 1990 г. истекли сроки действия Генеральных договоров на закрепление охотничьих угодий со всеми охотпользователями, и, по инициативе Леноблохотуправления, сроки их действия не были пролонгированы. В связи с распадом СССР в 1991 г. существенно изменились социально-экономические условия, и это имело катастрофические последствия для охотничьего хозяйства Ленинградской области.

В этот период, согласно Приказа Леноблохотуправления, все охотничьи угодья получили статус угодий общего пользования, а профильные заказники - статус охотничье-производственных участков [15]. Таким образом, внедрялась эгалитарная модель охотничьего хозяйства и тип промысловых охотничьих хозяйств с экстенсивным методом использования охотничьих животных. Практически это выразилось в том, что на всей территории Ленинградской области: отсутствовал охотничий надзор; охотники-индивидуалы и группы охотников производили охоту самостоятельно без егерского сопровождения; биотехнические мероприятия никто не осуществлял; нарастало всеобщее ощущение правового нигилизма; промысловые охотничьи хозяйства поставляли мясо копытных животных (лося) на рынок, а скачкообразная инфляция превращала в ничто доходы от его продаж. Охотничьи угодья Ленинградской области, имея в своих соседях такой мегаполис, как Санкт-Петербург, оказались отданы на разграбление бесконтрольной армии охотников. В результате этого за семь лет, к 1997 г., лимит добычи лосей и кабанов сократился в 20 раз и составлял, соответственно, 155 особей лося и 80 особей кабана на 7,5 млн га. При этом численность лося сократилась в 3 раза и составляла 6,0-7,0 тыс. особей, кабана - в 5-6 раз и составляла 1,0-1,2 тыс. особей. Подобной катастрофы более не произошло ни в одном субъекте Российской Федерации в этот период, так как где-то охотничье хозяйство спасли большие малочисленные территории, где-то сохранился порядок и преемственность государственной политики еще советских времен. И, хотя в целом в России 1990-е гг. негативно отразились на охотничьем хозяйстве в Европейской части, нигде не было такого апокалипсического эффекта, как в Ленинградской области. А в тех регионах, где сохранился порядок охотпользования советского периода, например, Ярославской, Московской, Смоленской, Новгородской областях, в 1990-х гг. ущерб был самый незначительный.

Таким образом, внедрение эгалитарной модели охотничьего хозяйства с экстенсивным типом использования аборигенных видов охотничьих животных убедительно показывает неприемлемость использования такой модели в густонаселенных районах. Кроме того, охотничьи угодья в густонаселенных районах и вблизи крупных мегаполисов испытывают большую нагрузку от иных видов рекреационной активности дачников и садоводов, ягодников и грибников, рыболовов и туристов.

Следующим этапом развития охотничьего хозяйства Ленинградской области следует считать период 1998-2005 гг., когда началась работа по предоставлению территорий, акваторий для осуществления пользования объектами животного мира, активизация работы по осуществлению биотехнических мероприятий для основных видов охотничьих животных. В этот же самый период произошло улучшение охраны охотничьих угодий, ужесточение контроля за производством охоты на копытных и медведей, возобновилась работа по стимулированию добычи волков в виде выплат компенсаций, были внедрены скандинавский метод управления популяцией лося, а также европейские требования при эксплуатации популяции кабанов [2].

Органы государственного охотничьего надзора были обеспечены необходимым автомототранспортом, лодками с подвесными лодочными моторами, горюче-смазочными материалами, вспомогательным и сельскохозяйственным инвентарем. Штатный состав Леноблохотуправления увеличился со 106 до 134 штатных единиц. В результате данных мероприятий более $50 \%$ охотничьих угодий - около 4,0 млн га - было предоставлено охотпользователям, и там началась реальная деятельность по использованию, охране и воспроизводству охотничьих животных под жестким контролем Леноблохотуправления. На территориях охотничьих заказников общей площадью около 0,5 млн га эту работу осуществляло непосредственно Леноблохотуправление. Приказами Леноблохотуправления нормировалась добыча копытных по половозрастному признаку при участии контролирующих лиц.

Принцип избирательной селекционной добычи копытных начал внедряться в общественное сознание через СМИ, работников, нанятых охотпользователями, а также посредством сбора фрагментов челюстей добытых копытных (лосей) с целью контроля за возрастом и соответствия их возрастной категории разрешению на добычу, а также получения дополнительной информации о состоянии и тенденциях развития местной региональной популяции. Таким образом, в процесс избирательной по половозрастному признаку добычи лосей были вовлечены все охотники, участвующие в охоте, что способствовало эффективной и быстрой популяризации этого метода, а если возрастная категория добытого животного не соответствовала разрешению на добычу, то это являлось основанием для административного преследования нарушителей.

Результат от всего проведенного комплекса работ превзошел ожидаемые прогнозы и надежды. К 2004 г. численность лосей практически удвоилась и достигла 11,0 тыс. особей, кабанов увеличилась в 4 раза и достигла 4,5 тыс. особей [3]. Численность волков снизилась до 300 особей, и их ежегодная добыча составляла около 100 особей. Несмотря на рост численности диких хищников (лисиц, енотовидных собак, куниц, норок), благодаря вакцинации удалось избежать распространения бешенства в Ленинградской области, которая граничит с Эстонией и Псков- 
ской областью, на территории которых наблюдаются природные очаги этого заболевания, а кроме того, имелись случаи обнаружения заболевших животных в Новгородской и Вологодской областях.

Период наиболее эффективного управления сферой охотничьего хозяйства в Ленинградской области закончился в 2005 г. в связи с инициативой Правительства Российской Федерации, в результате которой были ликвидированы охотдепартамент Минсельхоза РФ и его территориальные органы - управления охотничьего хозяйства во всех регионах РФ. Это произошло вследствие административной реформы федеральных органов исполнительной власти, оценку результатов которой так и не дали до сих пор [5]. В процессе реализации административной реформы полномочия в сфере охотничьего хозяйства с 2005 г. были переданы федеральной службе Россельхознадзора Минсельхоза РФ и его территориальным органам.

Для охотничьего хозяйства Ленинградской области этот период характеризуется как время утраченного контроля за состоянием охраны, воспроизводства и использования охотничьих животных; разворовывания материальной базы Леноблохотуправления, переданной Управлению Россельхознадзора по СанктПетербургу и Ленинградской области; отсутствия и утраты статистических данных по учетам численности и добыче охотничьих животных; создания социальной напряженности в связи с непродуманными и необоснованными решениями по ограничению сезонов охоты; иных негативных решений, повлиявших на экономику в сфере оборота оружия, боеприпасов, снаряжения и амуниции, а также при оказании услуг гражданам при организации коммерческих охот [5]. В этот период образовался правовой и законодательный вакуум, некоторые аспекты которого не устранены даже принятым в 2009 г. федеральным законом от 24.07.2009 г. № 209-Ф3 «Об охоте и о сохранении охотничьих ресурсов и о внесении изменений в отдельные законодательные акты Российской Федерации» $[16,17]$.

Уже в 2007 г. министр сельского хозяйства РФ А.В. Гордеев признал ошибочность решений о передаче полномочий в сфере охотничьего хозяйства Россельхознадзору - в связи с полной утратой управляемости и надлежащего контроля. В федеральный закон от 24.04.1995 г. № 52-Ф3 «О животном мире» были внесены изменения, согласно которым исполнение федеральных полномочий в сфере охотничьего хозяйства было передано субъектам РФ. Для их исполнения регионам РФ передавалось финансирование в виде субвенций из федерального бюджета, штатная численность и материальная база из Россельхознадзора, обеспечившая деятельность в этой сфере [17]. Однако следует отметить, что к тому времени штатная численность работников управления Россельхознадзора по Санкт-Петербургу и Ленинградской области, занятых в сфере охотничьего хозяйства, составляла 30 человек; материальная база, в основном, была или разграблена, или утрачена, или пришла в негодность; передачу материальных ценностей невозможно было осуществить по формальным признакам, так как объекты были зарегистрированы как собственность Леноблохотуправления, не ликвидированного до сих пор. Решение Правительства РФ от 2005 г. до сих пор не исполнено.
Таким образом, в период 2005-2007 гг. был утрачен контроль в сфере охотничьего хозяйства, разграблена и утрачена материальная база охотнадзора, образовался нормативно-правовой вакуум, утрачены преемственность и статистика по учетам численности и добыче охотничьих животных [5].

Во исполнение федерального закона от 24.04.1995 г. № 52-Ф3 «О животном мире» (с последующими изменениями) в мае 2008 г. в составе администрации Ленинградской области был создан Комитет по охране, контролю и регулированию использования объектов животного мира (далее Комитет). Формирование штатного состава и создание материальной базы в очередной раз началось с нуля. В этот период продолжилась работа по предоставлению территорий, акваторий для осуществления пользования объектами животного мира охотпользователям, которая, в основном, была закончена к 1 апреля 2010 г., когда изменился порядок предоставления территорий, существующий по настоящее время, - на основе аукционов. К этому моменту более $90 \%$ охотничьих угодий было предоставлено охотпользователям. Штатный состав Комитета насчитывал 37 человек. Для обеспечения функционирования Комитета и осуществления полномочий было создано государственное учреждение «Леноблохота», штатный состав которого составлял 30 человек. На первоначальном этапе, при отсутствии материальной базы и автомототранспортных средств, контроль за деятельностью охотпользователей не мог быть эффективным. Для стабилизации ситуации был использован «метод обращения к здравому смыслу» охотпользователей, имеющих долгосрочные договоры и лицензии.

В 2010 г. в Ленинградской области сложилась следующая система охотпользования, при которой из 90 охотпользователей (имеющих 153 охотничьих хозяйства) $25 \%$ составляли общественные объединения охотников (за ними было закреплено около $52 \%$ всех охотничьих угодий), 75\% - остальные охотпользователи, работающие по принципу закрытых клубов (за ними было закреплено 48\% угодий). Такое распределение охотничьих угодий позволяет охотникам из малообеспеченных слоев населения пользоваться возможностью осуществления права на охоту в охотничьих угодьях общественных объединений или угодьях общего пользования по доступным ценам.

На основании федерального закона от 24.07.2009 г. № 209-Ф3 «Об охоте и о сохранении охотничьих ресурсов и о внесении изменений в отдельные законодательные акты Российской Федерации» к настоящему времени сформированы нормативы, которые во многом не стимулируют развитие охотничьего хозяйства. Например, предусмотренная законом норма о необходимости иметь $20 \%$ общедоступных охотничьих угодий во всех субъектах РФ оборачивается в густонаселенных регионах видимостью социальной справедливости. В то же время, несмотря на множество изменений, внесенных за этот период в Кодекс административных правонарушений и Уголовный кодекс, эти нормативные акты не позволяют эффективно бороться с браконьерством [5].

В связи с отсутствием жесткого контроля и надзора со стороны государственных органов, в настоящий момент сложилась ситуация, когда охотпользователи формально исполняют требования законодатель- 
ства по предоставлению отчетов и информации, в то же время используют охотничьи ресурсы на территории своих охотничьих угодьев так, как считают нужным, - в пользу своих собственных интересов [16]. Имеются факты и свидетельства использования некоторых видов охотничьих ресурсов, превышающего квоты, установленные самими охотпользователями, больше чем в 2-3 раза. Такая ситуация имеет место в тех охотничьих хозяйствах, на территории которых их владельцы, являясь представителями региональной деловой или политической (административной) элиты, чувствуют свою безнаказанность и руководствуются собственными понятиями и потребностями. Информация о подобных фактах быстро распространяется в охотничьих кругах и в других охотничьих угодьях, увеличивая с каждым годом протестное браконьерство. Эти явления наряду с неграмотными требованиями федерального законодательства по эксплуатации лосиного стада привели к тому, что темпы роста численности лосей затормозились в значительной степени и потеряли динамику начала 2000-х гг.

Тем не менее, в Ленинградской области численность лосей постепенно растет, растет и лимит и квоты их добычи. Численность кабанов стабилизировалась на достаточно высоком уровне. Социальных взрывов на почве охотничьей нестабильности не наблюдается. Благодаря федеральному законодательству общественные организации охотников потеряли свои былые позиции, так как большинство из них оказалось по существу приватизировано.

Таким образом, после всех катаклизмов и изменений в настоящий момент сложилась ситуация, когда органы власти и управления охотничьим хозяйством «утонули» во всевозможных отчетах и информациях на бумажных и электронных носителях в соответствии с требованиями федерального законодательства и Перечнями поручений Президента РФ. В то же время из-за малочисленности штата они не успевают контролировать реальную деятельность охотпользователей. В свою очередь, охотпользователи, которые должны вовремя и достаточно полно отчитаться и предоставить требуемую информацию органам исполнительной власти, придерживаются в своей охотхозяйственной деятельности собственных приоритетов, сформированных реалиями и варьирующих в зависимости от общественной значимости их владельцев. Тем временем животный мир развивается по своим биологическим законам, на наш взгляд, более объективным, нежели придуманным федеральными и региональными властными структурами, а охотники нашли свои ниши для реализации возможности охоты по своему собственному разумению, учитывая несовершенство законодательства.

\section{Основные положения Концепџии развития охотничьего хозяйства Ленинградской области на десятилетний период}

Изучение исторического опыта состояния и развития охотничьего хозяйства Ленинградской области, пики и спады которого за последние 30 лет происходили под влиянием изменений социальноэкономических условий и административных реформ, установление причинно-следственных связей этих процессов, объективная оценка результатов происходящего дают основание предложить модель развития охотничьего хозяйства Ленинградской области и План реализации действий в этой сфере на ближайшую перспективу.

Концепция развития охотничьего хозяйства Ленинградской области должна согласовываться также с основными положениями «Стратегии развития охотничьего хозяйства Российской Федерации до 2030 года», утвержденной распоряжением Правительства РФ от 03.07.2014 г. № 1216-р. Однако вышеуказанная стратегия не учитывает того, что ее основные положения были уже реализованы более 30 лет назад, и ныне сформулированная задача ее реализации к 2030 г. позволяет констатировать, что охотничье хозяйство РФ в результате социально-экономических изменений, административных реформ и ее последствий, правовой и финансовой нестабильности отброшено назад на 50 лет. Осознание этого факта в значительной степени накладывает на всех заинтересованных лиц ответственность при выработке рекомендаций и подготовке программных документов в ближайший период.

Исходя из общей теории охоты, исторического опыта и стратегических направлений развития охотничьего хозяйства Российской Федерации, развитие охотничьего хозяйства Ленинградской области на ближайшие 10 лет, по нашему мнению, должно основываться на следующих положениях.

- Использовать эгалитарную модель охотничьего хозяйства, согласно которой все площади охотничьих угодий предоставлены юридическим лицам любой формы собственности и индивидуальным предпринимателям для осуществления пользования объектами животного мира на долгосрочной основе.

- Обеспечить реальное управление и контроль за деятельностью охотпользователей региональными органами исполнительной власти для преодоления инерционного развития и экстенсивного использования аборигенных видов охотничьих животных.

- Обеспечить совершенствование нормативно-правовой базы в целях повышения эффективности охраны охотничьих угодий, улучшения условий использования охотничьих ресурсов и их расширенного воспроизводства, совместимости с законодательством других сфер природопользования.

- Стимулировать деятельность по регулированию численности диких плотоядных животных в целях поддержания устойчивости экологических систем и борьбы с заболеваниями диких животных.

- Пропагандировать и стимулировать деятельность по реакклиматизации и акклиматизации, дичеразведению и разведению охотничьих животных, вовлечению в хозяйственный оборот новых видов охотничьих ресурсов.

- Обеспечить условия доступности охоты для всех слоев населения в охотничьих хозяйствах, независимо от форм собственности, а также обеспечить поддержку общественных объединений охотников в целях расширения их участия для достижения социально-экономических результатов.

- Обеспечить подготовку кадрового резерва специалистов для государственных органов управления охотничьим хозяйством и охотпользователей в специализированных учебных учреждениях.

- Обеспечить пропаганду имиджа охоты и охотничьего хозяйства среди населения как сферы деятельности, имеющей существенное природоохран- 
ное значение, без которого невозможно увеличение биоразнообразия и численности диких животных, управление их популяциями.

- Обеспечить международное сотрудничество с сопредельными государствами, использовать общие методы и принципы оценки численности и использования охотничьих ресурсов на едином экологическом пространстве.

Реализация вышеуказанных положений концепции развития охотничьего хозяйства Ленинградской области на ближайшую перспективу возможна посредством следующих мер:

- инициирование внесения изменений в нормы федерального законодательства и совершенствования нормативно-правовой базы в части:

- изменения нормативов допустимого изъятия и норм допустимой добычи охотничьих животных определенных возрастных и половых групп;

- уточнения порядка регулирования численности на всех территориях, направленного на поддержание устойчивости экологических систем;

- введения нулевых размеров ставок платы за добычу таких видов, как волк, енотовидная собака, лисица, американская норка;

- создание эффективной системы охраны охотничьих ресурсов, увеличение штатного состава органа исполнительной власти Ленинградской области, исполняющего контрольно-надзорные полномочия;

- стимулирование регулирования численности таких видов, как волк, енотовидная собака, лисица, американская норка, для поддержания устойчивости экологических систем и борьбы с болезнями животных;

- восстановление ареала и вовлечение в хозяйственный оборот косули европейской;
- стимулирование работ по расширенному воспроизводству охотничьих ресурсов, дичеразведению как аборигенных видов, так и акклиматизированных в Ленинградской области, разведению охотничьих животных в полувольных условиях;

- осуществление контроля учета интересов охотничьего хозяйства при реализации крупных инфраструктурных проектов;

- осуществление мероприятий и программ приграничного сотрудничества с сопредельными странами, другими субъектами РФ;

- обеспечение подготовки кадрового резерва специалистов в специализированных учебных заведениях;

- создание учебно-опытных охотничьих хозяйств на базе некоторых ООПТ регионального значения и ФГУ, переданных в Ленинградскую область;

- внедрение в практику ведения охотничьего хозяйства наилучших доступных технологий для долгосрочного устойчивого использования и расширенного воспроизводства охотничьих ресурсов;

- стимулирование привлечения инвестиций для обеспечения устойчивого и экономически эффективного использования охотничьих ресурсов;

- обеспечение совместимости нормативно-правовой базы в сфере охотничьего хозяйства с документами лесного планирования;

- стимулирование развития охотничьего туризма, развитие трофейной охоты;

• поддержка и развитие традиционных видов охот с использованием собак охотничьих пород, ловчих и манных птиц;

- изменение имиджа охоты в общественном сознании путем популяризации культуры «правильной» охоты через СМИ;

- обеспечение эффективного контроля за деятельностью охотпользователей.

\section{Литература}

1. Гайст B. Россия и зарубежный опыт // Охота. Национальный охотничий журнал. 2009. - № 7.

2. Глушков B.M. Зарубежный опыт управления ресурсами лося // Охотоведение: Зарубежный опыт охотничьего хозяйства. -2004 . - № 2 (52). - C. 145-153.

3. Государственный доклад. О состоянии окружающей среды Санкт-Петербурга и Ленинградской области в 2002 году. - СПб. : Главное управление природных ресурсов по Санкт-Петербургу и Ленинградской области МПР РФ. - 2004. - 209 с.

4. Захарова Е.Ю. Теория экологически ориентированного антропоцентризма // Ученые записки Забайкальского государственного университета. - 2013. - № 4 (51). - С. 16-21.

5. Кожаев A.A. Практическая реализация принципов управления популяциями охотничьих животных в Российской Федерации // Динамика популяций охотничьих животных Северной Европы: Материалы VI Междуна- родного симпозиума. - Петрозаводск, 2014. C. $127-128$.

6. Кокин A.B. Ассимиляционный потенциал биосферы. - Ростов н/Д : СКАГС, 2005. - 205 с.

7. Матвейчук С.П. Государство, отрасль, охотники: проблемы взаимодействия // Труды ВНИИОЗ. - 2000. - № 1 (51). - С. 65-94.

8. Матвейчук С.П. Элитарность и эгалитарность в российской охоте // Современные проблемы природопользования, охотоведения и звероводства: Материалы Международной научно-практической конференции. - Киров : ВНИИОЗ, 2007. - С. 271-273.

9. Саймон Д. Неисчерпаемый ресурс. - Челябинск : Социум, 2009. - 170 с.

10. Сафонов В.Г. Проблемы охотничьего хозяйства России // Труды ВНИИОЗ. - 2000. № 1 (51). - C. 17-23.

11. Сафонов В.Г. Перспективы охоты и охотхозяйственной деятельности в современном обществе // Современные проблемы природопользования, охотоведения и звероводст- 
ва: Материалы Международной научно-практической конференции. - Киров : ВНИИОЗ, 2002. - C. 79-82.

12. Сафонов В.Г. Социально-экономическое значение охоты и спортивного рыболовства в США // Охотоведение. - 2004. - № 2 (52). C. $30-42$.

13. Сафонов В.Г. Современное использование ресурсов охотничьих животных в Германии и Австрии // Охотоведение. - 2004. - № 2 (52). C. $114-117$.

14. Сафонов В.Г. Об эффективности реформ в сфере охотничьего хозяйства и его научного обеспечения // Охотоведение. - 2006. № 3 (53). - C. 122-136.
15. Тарбаева В.М., Лукина Е.А., Михеева Е.А., Нагаева С.П. Проблемы и перспективы развития особо охраняемых природных территорий (ООПТ) Северо-Запада России // Научно-технические ведомости СПбГПУ. - 2003. - № 4. С. 196-199.

16. Тарбаева B.M. Организация мониторинга проблем состояния местообитаний охотничьих животных в регионах СЗФО // Динамика популяций охотничьих животных Северной Европы: Материалы VI Международного симпозиума. - Петрозаводск, 2014. - С. 163-164.

17. Чащухин B.A. Охота на разных континентах // Охотоведение. - 2004. - № 2 (52). C. $14-29$.

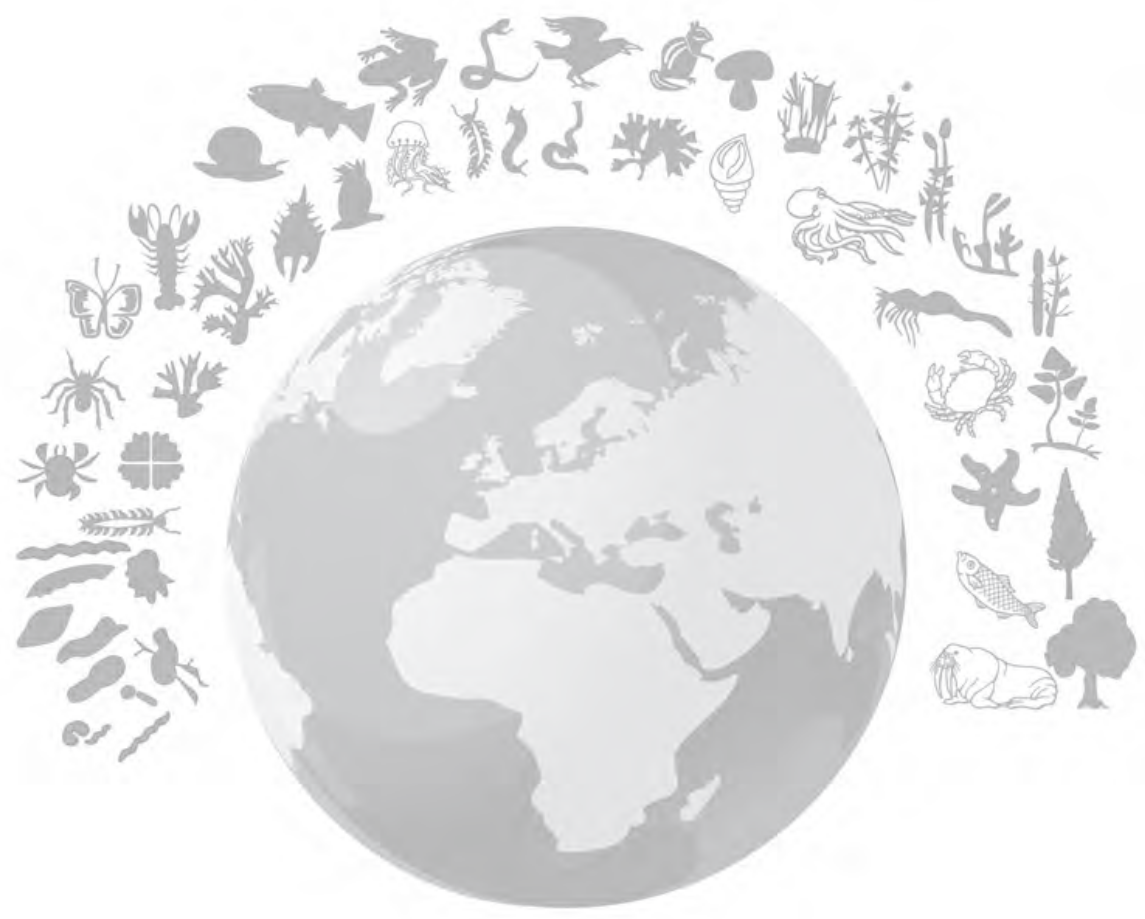

